\title{
Cell death sensitization of leukemia cells by opioid receptor activation
}

\author{
Claudia Friesen ${ }^{1,2}$, Mareike Roscher ${ }^{1,2}$, Inis Hormann ${ }^{1,2}$, Iduna Fichtner ${ }^{3}$, Andreas \\ Alt $^{2}$, Ralf A. Hilger ${ }^{4}$, Klaus-Michael Debatin ${ }^{5}$, Erich Miltner ${ }^{1,2}$ \\ ${ }^{1}$ Center for Biomedical Research, University of UIm, UIm, Germany \\ 2 Institute of Legal Medicine, University of UIm, Ulm, Germany \\ 3 Max Delbrueck Center for Molecular Medicine, Berlin, Germany \\ ${ }^{4}$ Department of Internal Medicine, University of Essen, West German Cancer Center, Essen, Germany \\ ${ }^{5}$ University Children's Hospital, University of UIm, Ulm, Germany \\ Correspondence to: Claudia Friesen, email: claudia.friesen@uni-ulm.de \\ Keywords: opioids, methadone, doxorubicin, cAMP, apoptosis, acute lymphoblastic leukemia \\ Received: March 27, $2013 \quad$ Accepted: April 14, $2013 \quad$ Published: April 16, 2013
}

This is an open-access article distributed under the terms of the Creative Commons Attribution License, which permits unrestricted use, distribution, and reproduction in any medium, provided the original author and source are credited.

\section{ABSTRACT:}

Cyclic AMP (CAMP) regulates a number of cellular processes and modulates cell death induction. CAMP levels are altered upon stimulation of specific G-protein-coupled receptors inhibiting or activating adenylyl cyclases. Opioid receptor stimulation can activate inhibitory $\mathbf{G}_{\mathrm{i}}$-proteins which in turn block adenylyl cyclase activity reducing CAMP. Opioids such as D,L-methadone induce cell death in leukemia cells. However, the mechanism how opioids trigger apoptosis and activate caspases in leukemia cells is not understood. In this study, we demonstrate that downregulation of cAMP induced by opioid receptor activation using the opioid D,L-methadone kills and sensitizes leukemia cells for doxorubicin treatment. Enhancing cAMP levels by blocking opioidreceptor signaling strongly reduced $D, L-m e t h a d o n e-i n d u c e d$ apoptosis, caspase activation and doxorubicin-sensitivity. Induction of cell death in leukemia cells by activation of opioid receptors using the opioid $D, L-$ methadone depends on critical levels of opioid receptor expression on the cell surface. Doxorubicin increased opioid receptor expression in leukemia cells. In addition, the opioid D,L-methadone increased doxorubicin uptake and decreased doxorubicin efflux in leukemia cells, suggesting that the opioid D, L-methadone as well as doxorubicin mutually increase their cytotoxic potential. Furthermore, we found that opioid receptor activation using $D, L-m e t h a d o n e$ alone or in addition to doxorubicin inhibits tumor growth significantly in vivo. These results demonstrate that opioid receptor activation via triggering the downregulation of CAMP induces apoptosis, activates caspases and sensitizes leukemia cells for doxorubicin treatment. Hence, opioid receptor activation seems to be a promising strategy to improve anticancer therapies.

\section{INTRODUCTION}

Acute lymphoblastic leukemia (ALL) is the most frequent malignant disease in children but affects adolescents as well [1]. The intensification of treatment regimens and advances in supportive care, improved the survival rates of childhood ALL to $80 \%$, whereas in adults the overall survival rate remains at approximately $40 \%[2,3]$. Unfortunately, patients suffering from relapse have a poor outcome [4] which is mainly determined by the response to chemotherapy, involving a number of deregulated pathways like differentiation, survival and apoptosis [3, 5-7].

The main goal in chemotherapies is the concerted destruction of cells via apoptosis $[8,9]$. Apoptosis can be mediated via the external death receptor/ligand pathway or the intrinsic pathway involving caspases [8-10]. Proapoptotic proteins like Bax and anti-apoptotic proteins 
(Bcl-2, Bcl- $\mathrm{x}_{\mathrm{L}}, \mathrm{XIAP}$ ) frequently involved in malignancies and treatment resistances regulate apoptosis induction [7, 11-14].

Previous studies showed that the second messenger cyclic AMP (cAMP) inhibits doxorubicin as well as DNAdamage-induced apoptosis $[15,16]$. cAMP regulates a number of cellular processes. The production of cAMP is either increased or decreased upon stimulation of G-protein-coupled receptors which activate or inhibit adenylyl cyclases. cAMP is responsible for a multitude of actions like ion channel regulation and kinase activation [17-19]. Furthermore, cAMP can either stimulate or inhibit programmed cell death [20].

Methadone is a full-opioid agonist used as substitution for heroin or other opiates but also as longlasting analgesic in cancer pain [21]. Opioid receptor activation initiates a cascade of events resulting in a diversity of biological effects like analgesis, sedation but also effects on cell survival and proliferation can be observed [22-25]. Opioid receptor stimulation can activate inhibitory Gi-proteins which in turn block adenylyl cyclase activity reducing cAMP [17].

The opioid D,L-methadone induces apoptosis in human T-lymphoblastic and myeloid leukemia cell lines and overcomes chemoresistance in leukemia cells without affecting healthy lymphocytes [25]. Singh et al found an effective synergism in cell death induction using D,L-methadone in addition to an anti-Bcl-2-agent [23]. Furthermore, D,L-methadone strongly inhibits proliferation of leukemia and human lung cancer cell lines [22, 25-27].

In this study, we found that opioid receptor activation induces cell death sensitization of leukemia cells ex vivo and in vivo. Our work provides evidence that the downregulation of cAMP induced by opioid receptor triggering induces apoptosis, activates caspases and sensitizes leukemia cells for doxorubicin treatment. In addition, we demonstrate that the opioid D,Lmethadone-induced cell death depends on critical levels of opioid receptor expression which can be increased by doxorubicin. Additionally, D,L-methadone increases doxorubicin influx and hampers its efflux in leukemia cells.

\section{RESULTS}

\section{D,L-Methadone induces cell death in xenograft- derived ALL cells depending on opioid receptor expression}

The opioid D,L-methadone induces cell death in different leukemia cell lines [25]. To test the role of opioid receptor triggering in cell death induction and the clinical relevance of D,L-methadone in treatment of leukemia, we analyzed the anti-cancer effect of D,Lmethadone in different xenograft-derived ALL cells. The xenografts were originally established from patients with T-cell (ALL-SCID6, ALL-SCID3), B-cell (ALL-SCID7) [28] and B-cell precursor (BCP, pre-B-ALL-SCID) acute leukemia. First, we measured opioid-receptor expression on xenograft-derived ALL cells. ALL-SCID6, ALLSCID3, and ALL-SCID7 leukemia cells displayed high amounts of opioid-receptors whereas the pre-B-ALLSCID leukemia cells expressed only moderate levels of opioid-receptors (Figure 1A). To analyze if cell death induction using D,L-methadone depends on the levels of opioid receptor expression, we treated the xenograftderived ALL cells with different concentrations of D,Lmethadone (Figure 1B). We used therapeutic plasma concentrations of $\mathrm{D}, \mathrm{L}$-methadone $(\leq 3 \mu \mathrm{g} / \mathrm{mL})$ and included $10 \mu \mathrm{g} / \mathrm{mL}$ D,L-methadone, because levels of $\mathrm{D}, \mathrm{L}-\mathrm{methadone}$ in lymphatic tissue and marrow might be higher [23]. Therapeutic plasma concentrations of $\mathrm{D}$,L-methadone $(\leq 3 \mu \mathrm{g} / \mathrm{mL})$ induced a strong cell death in xenograft-derived ALL cells (Figure 1B) expressing high amounts of opioid-receptors (Figure 1A). In contrast, the xenograft-derived-BCP-ALL cells (pre-BALL-SCID) expressing moderate opioid-receptor levels (Figure 1A) could only be slightly killed with therapeutic concentrations of D,L-methadone (Figure 1B). Therefore, apoptosis induction by D,L-methadone seems to depend on the level of opioid-receptor expression.

\section{D,L-methadone sensitizes ALL-cells for doxorubicin-induced cell death and caspase activation}

In analogous studies, we tested the cytotoxic potential of D,L-methadone on BCP-ALL cell lines (Tanoue, Reh, Nalm6) expressing opioid-receptors in a moderate level on their cell surface (Figure 2A). These BCP-ALL cell lines could only be killed slightly by D, L-methadone (Figure 2B) as observed for xenograftderived-BCP-ALL cells (pre-B-ALL-SCID) (Figure 1B). As different substances can act synergistically, we treated Tanoue, Reh, Nalm6, and xenograft-derived-BCP-ALL cells (pre-B-ALL-SCID) with different concentrations of $\mathrm{D}, \mathrm{L}$-methadone and doxorubicin alone or in combination with each other (Figure $2 \mathrm{~B}, 2 \mathrm{C}$ and 2D). We observed that the combination treatment strongly killed the BCPALL cell lines (Figure $2 \mathrm{~B}$ ) and strongly reduced survival of BCP-ALL cell lines markedly (Figure 2C). The combination treatment also strongly killed xenograftderived-BCP-ALL cells (pre-B-ALL-SCID) (Figure 2D).

To analyze the molecular pathways of cell killing in more detail and to find out how the combination treatment with D,L-methadone and doxorubicin induced apoptosis, we analyzed which apoptotic effector molecules are activated in BCP-ALL cells upon this combination 
treatment compared to cells treated with D,L-methadone or doxorubicin alone. $120 \mathrm{~h}$ after treating the BCP-ALL cell line Tanoue with D,L-methadone in addition to doxorubicin, we observed the activation of the caspase cascade in BCP-ALL cells. We found a strong activation of caspase- 3 and caspase- 9 and cleavage of the prototype substrate of caspase-3, PARP (Figure 3A).

The role of the caspase cascade in apoptosis induction was further investigated with the broad-spectrum inhibitor of caspases zVAD.fmk. zVAD.fmk strongly decreased cell death after combination treatment with D,Lmethadone and doxorubicin in BCP-ALL cells (Figure 3B) underlining the dependence on caspase activation.

The apoptotic machinery is tightly controlled by anti-apoptotic factors like XIAP and Bcl- $\mathrm{X}_{\mathrm{L}}[11,12]$ which we found to be strongly downregulated in BCP-ALL cells treated with $\mathrm{D}, \mathrm{L}-\mathrm{methadone}$ in addition to doxorubicin (Figure 3C). These results indicate that the combination of D,L-methadone and doxorubicin sensitizes BCP-ALL cells for apoptosis via the activation of caspases and downregulation of XIAP and Bcl- $\mathrm{x}_{\mathrm{L}}$.

\section{D,L-methadone enhances doxorubicin-uptake and inhibits doxorubicin-efflux whereas doxorubicin induces opioid-receptor expression}

The efficiency of cell death induction and activation of effector molecules in apoptosis pathways after treating leukemia cells with D,L-methadone seems to depend on the amount of opioid-receptors displayed on the cell's surface. Combination treatment with D,L-methadone and doxorubicin kills leukemia cells with moderate opioid receptor expression, which could only be killed slightly by D,L-methadone or doxorubicin alone. Chemotherapeutics enhance the expression of receptors like CD95 in leukemia cells [29]. To analyze whether doxorubicin might influence the opioid-receptor expression, we treated the BCP-ALL cell line Tanoue with doxorubicin for 96h. Afterwards, the relative amount of opioid-receptors compared to untreated cells was measured by flow cytometry. We found that doxorubicin strongly increased opioid-receptor expression (Figure 4A) suggesting that D,L-methadone can bind in higher amounts to cells co-treated with doxorubicin.

Opioids as well as doxorubicin are substrates

A


B
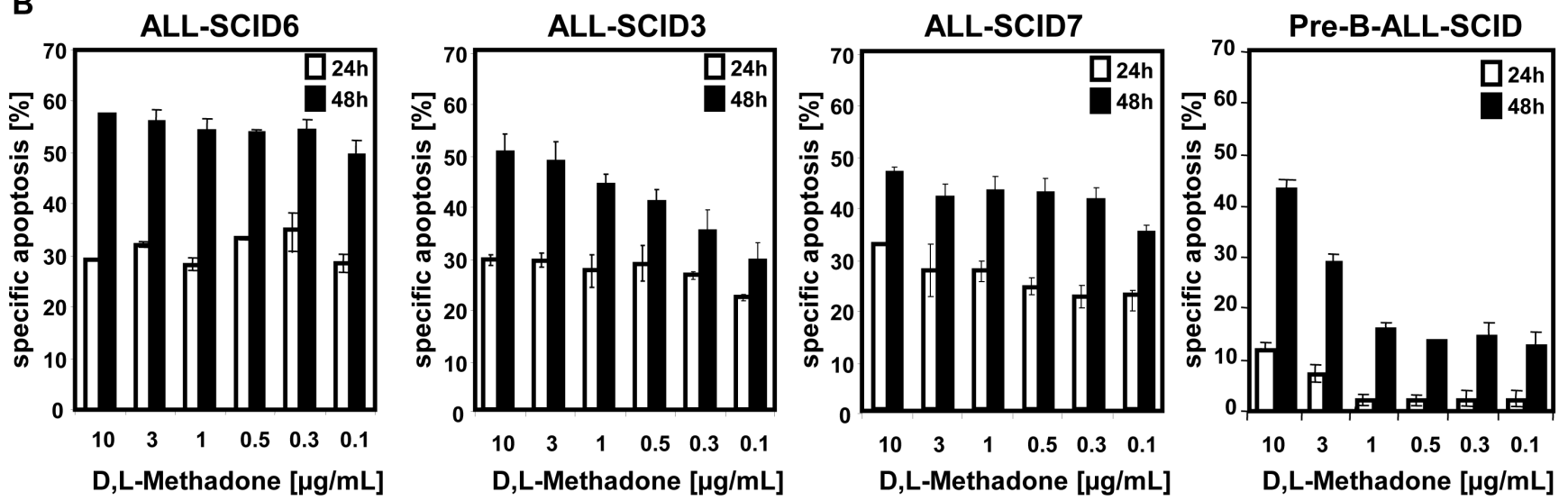

Figure 1: D,L-Methadone kills ALL cells ex vivo depending on critical levels of opioid receptor expression. (a) Human ALL-SCID6, ALL-SCID3, ALL-SCID7, and pre-B-ALL-SCID leukemia cells derived from xenografted mice display different levels of opioid-receptors on their cell surface. The cells were stained with naloxone-fluoresceine measuring opioid-receptor expression (OR, thick black curve) and analyzed by flow cytometry. Controls (Co, unstained cells) are exhibited as thin black curves. (b) ALL-SCID6, ALLSCID3, ALL-SCID7, and pre-B-ALL-SCID leukemia cells were treated with different concentrations of D,L-methadone (as indicated). After $24 \mathrm{~h}$ (white columns) and 48h (black columns), the fractions of apoptotic cells were measured by FSC/SSC-analysis. The percentage of specific apoptosis was calculated as follows: $100 \mathrm{x}$ [experimental dead cells (\%) - spontaneous dead cells in medium (\%)] / [100\% spontaneous dead cells in medium(\%)]. Columns, mean of triplicates; bars, $\mathrm{SD}<10 \%$. 
A



B

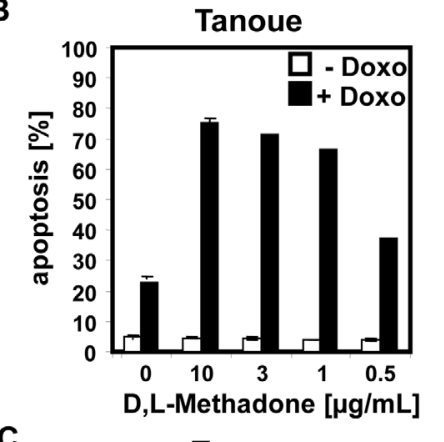

C

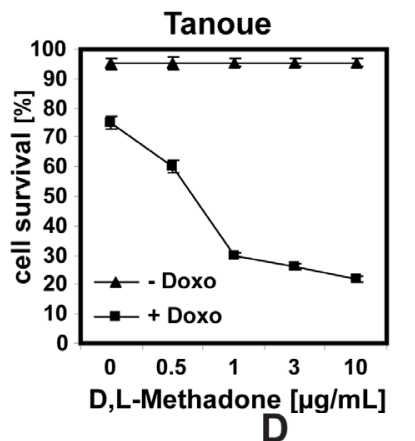

Nalm6

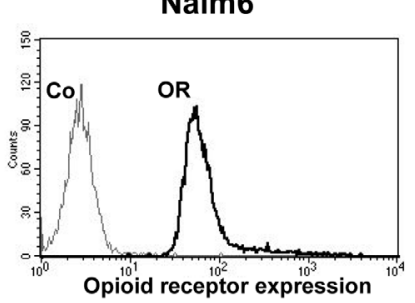

Nalm6

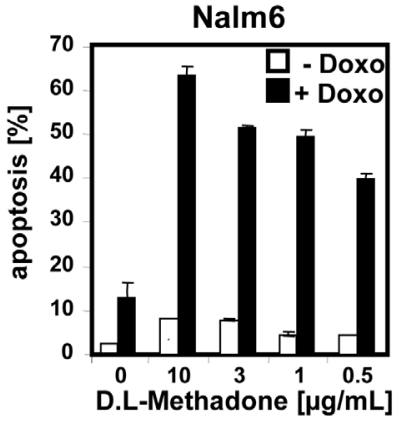

Nalm6

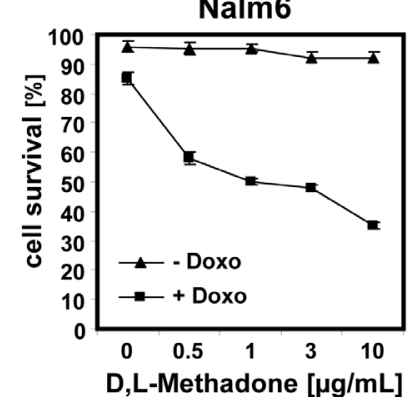

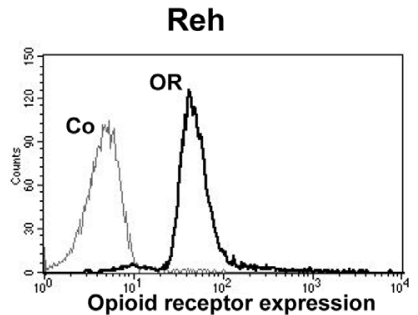

Reh
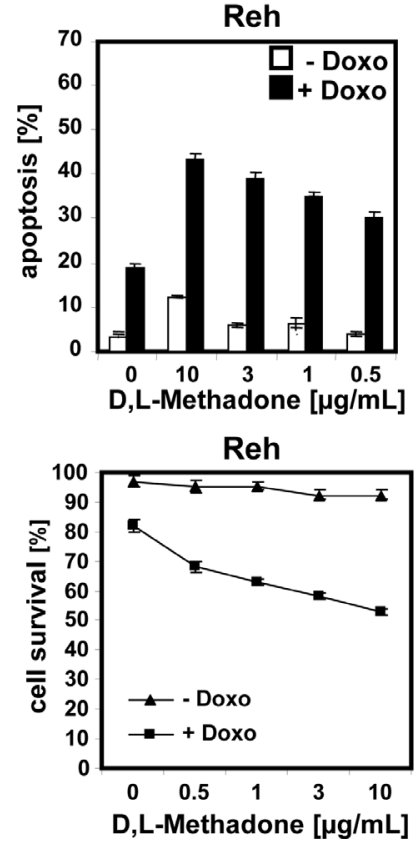

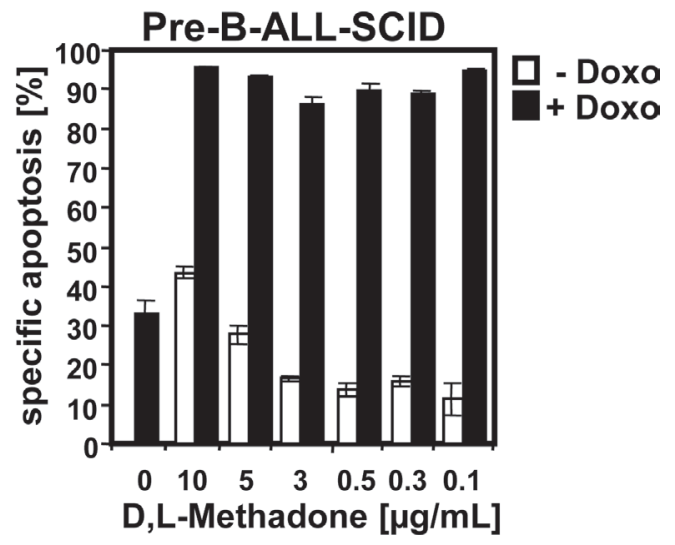

Figure 2: Combination treatment with D,L-methadone and doxorubicin induces apoptosis in ALL cells expressing moderate amounts of opioid receptors. (a) Different BCP-ALL cell lines (Tanoue, Nalm6 and Reh) express a moderate number of opioid-receptors on their cell surface. Tanoue, Nalm6 and Reh were stained with naloxone-fluoresceine measuring opioid-receptor expression (OR, thick black curve) and analyzed by flow cytometry. Controls (Co, unstained cells) are exhibited as thin black curves. (b) BCP-ALL cell lines (Tanoue, Nalm6 and Reh) were treated with different concentrations of D,L-methadone alone (- Doxo, white columns), with doxorubicin alone or with D,L-methadone in addition to doxorubicin (+ Doxo, black columns). For the cell line Tanoue, we used doxorubicin in a concentration of $0.06 \mu \mathrm{g} / \mathrm{mL}$, for Nalm6 and Reh in a concentration of $0.01 \mu \mathrm{g} / \mathrm{mL}$. 120h after stimulation, the percentages of apoptotic cells were measured by FSC/SSC-analysis. (C) BCP-ALL cell lines (Tanoue, Nalm6 and Reh) were treated with different concentrations of D,L-methadone alone (- Doxo, triangle), with doxorubicin alone or with D,L-methadone in addition to doxorubicin (+ Doxo, square). For the cell line Tanoue, we used doxorubicin in a concentration of $0.06 \mu \mathrm{g} / \mathrm{mL}$, for Nalm6 and Reh in a concentration of $0.01 \mu \mathrm{g} / \mathrm{mL}$. 120h after stimulation, the percentages of surviving cells were measured by FSC/SSC-analysis (D). D,L-Methadone strongly enhances doxorubicin sensitivity of xenograft-derived-BCP-ALL-cells ex vivo. Xenograft-derived-BCP-ALL cells (pre-B-ALL-SCID) were treated with different concentrations of D,L-methadone (as indicated) alone (- Doxo, white columns), with $0.01 \mu \mathrm{g} / \mathrm{mL}$ doxorubicin alone or with D,L-methadone in addition to doxorubicin (+ Doxo, black columns). $48 \mathrm{~h}$ after stimulation, the percentages of apoptotic cells were measured by FSC/SSC-analysis. The percentage of specific apoptosis was calculated as described in Figure 1B. Columns, mean of triplicates; bars, $\mathrm{SD}<10 \%$. 
of the in multi-drug resistances-involved efflux pump P-glycoprotein (P-gp). Furthermore, D,L-methadone is known to inhibit P-gp [30-33]. To analyze whether $\mathrm{D}, \mathrm{L}-\mathrm{methadone}$ might influence the uptake and/or efflux of doxorubicin in leukemia cells, the BCP-ALL cell line Tanoue was incubated for different intervals with doxorubicin alone or with a combination of doxorubicin and D,L-methadone. After 4h, 8h, 24h (maximum uptake), we observed an enhanced doxorubicin concentration in the cells co-incubated with doxorubicin and D,L-methadone (Figure 4B). 24h after maximum uptake of doxorubicin, doxorubicin was removed from the supernatant and fresh medium was added without doxorubicin and D,Lmethadone was applied. After $8 \mathrm{~h}$ and 24h, D,L-methadone reduced the doxorubicin efflux strongly (Figure 4C) indicating that D,L-methadone increases doxorubicin uptake and inhibits doxorubicin efflux out of leukemia cells. This suggests that D,L-methadone as well as doxorubicin mutually increase their cytotoxic potential.

\section{Apoptosis induction by D,L-methadone and doxorubicin depends on opioid receptor activation inducing CAMP downregulation}

To further analyze the role of opioid-receptor triggering in apoptosis induction and consequently activation of apoptotic pathways, the BCP-ALL cell line Tanoue was treated with D,L-methadone, doxorubicin or with the opioid-receptor antagonist naloxone alone or in different combinations with each other (Figure

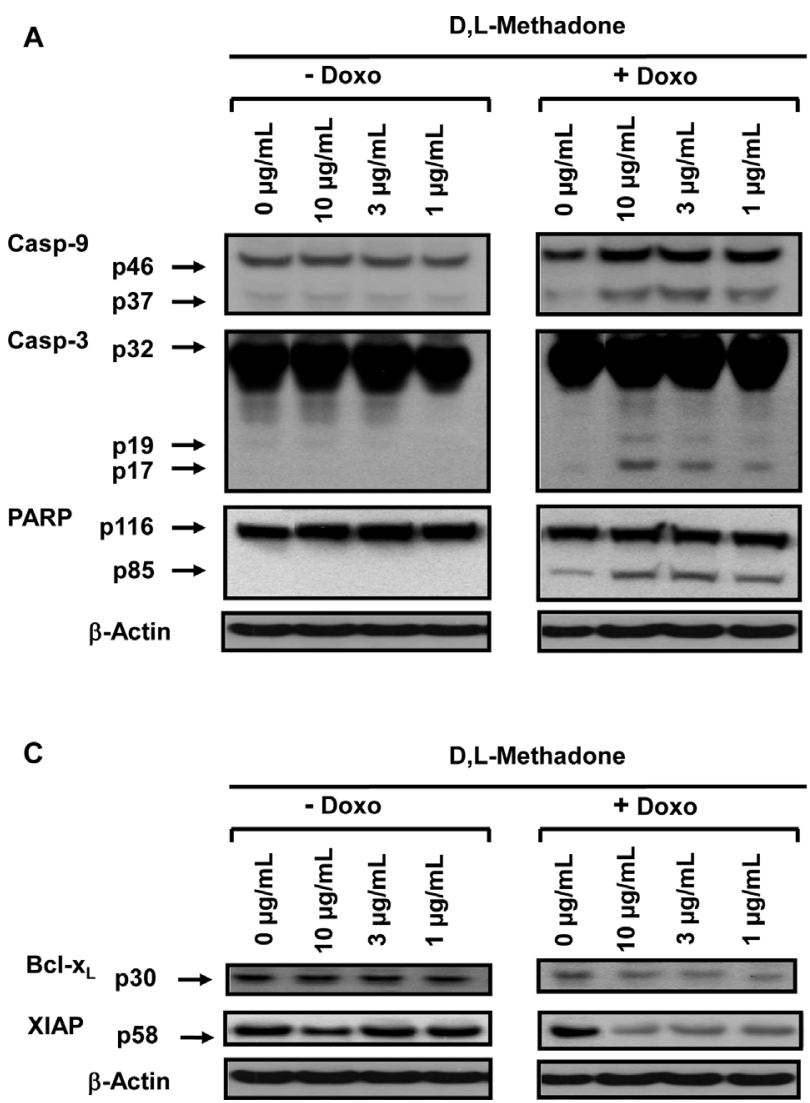

B

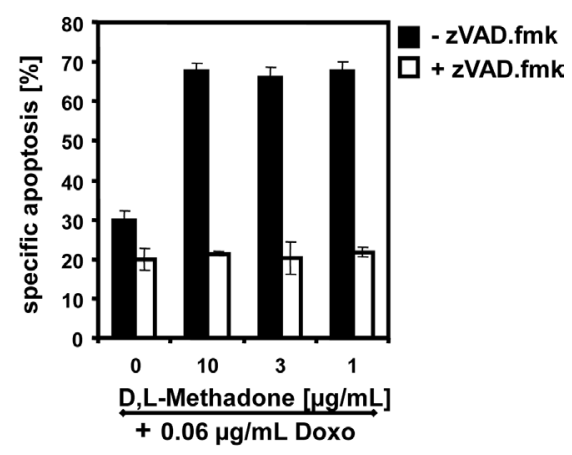

Figure 3: D,L-Methadone in combination with doxorubicin restores deficient activation of apoptotic pathways in BCP-ALL cells expressing moderate amounts of opioid receptors in vitro. (a) D,L-Methadone and doxorubicin co-treatment provokes caspase activation. The BCP-ALL cell line Tanoue was treated with different concentrations of D,L-methadone (as indicated) alone (- Doxo), with $0.06 \mu \mathrm{g} / \mathrm{mL}$ doxorubicin (+ Doxo) alone or with D,L-methadone in addition to doxorubicin (+ Doxo). After 120h, Western blot analyses for caspase-9, caspase-3 and PARP were performed. The active fragment of caspase- 9 was detected at $\sim 37 \mathrm{kDa}$, the active fragment of caspase- 3 at $\sim 19 \mathrm{kDa}$ and $\sim 17 \mathrm{kDa}$ and PARP cleavage at $\sim 85 \mathrm{kDa}$. Equal protein loading was controlled by anti- $\beta$-actin antibody. (b) D,L-Methadone and doxorubicin-induced apoptosis depends on caspase activation. Pre-incubation of the cell line Tanoue with $50 \mu \mathrm{M}$ of the caspase inhibitor zVAD.fmk for $1 \mathrm{~h}$ (white columns, + zVAD.fmk,) or without pre-treatment (black columns, - zVAD. fmk, ) was followed by addition of different concentrations of D,L-methadone (as indicated) in combination with $0.06 \mu \mathrm{g} / \mathrm{mL}$ doxorubicin. Apoptosis induction was detected $120 \mathrm{~h}$ after stimulation by FSC/SSC-analysis. The percentage of specific apoptosis was calculated as described in Figure 1B. Columns, mean of triplicates; bars, $\mathrm{SD}<10 \%$. (c) Downregulation of XIAP and Bcl- $\mathrm{x}_{\mathrm{L}}$ by D,L-methadone and doxorubicin co-treatment. The cell line Tanoue was treated with different concentrations of D,L-methadone (as indicated) alone (- Doxo), with $0.06 \mu \mathrm{g} / \mathrm{mL}$ doxorubicin (+ Doxo) alone or with D,L-methadone in addition to doxorubicin (+ Doxo). After 120h, Western blot analyses for XIAP and Bcl- $\mathrm{x}_{\mathrm{L}}$ were performed. XIAP was detected at $\sim 58 \mathrm{kDa}$ and $\mathrm{Bcl}-\mathrm{x}_{\mathrm{L}}$ at $\sim 30 \mathrm{kDa}$. Equal protein loading was controlled by anti- $\beta$-actin antibody. 
5A and 5B). After 96h, we found that blocking opioidreceptors by naloxone strongly reduced the apoptotic rates of the combination treatment with $\mathrm{D}, \mathrm{L}-\mathrm{methadone}$ and doxorubicin (Figure 5A). Additionally, naloxone cotreatment drastically reduced the activation of caspase- 9 and caspase- 3 and cleavage of PARP (Figure 5B) indicating that opioid-receptor triggering is involved in apoptosis induction and in caspase activation.

Opioid receptor stimulation activates inhibitory $\mathrm{G}_{\mathrm{i}}$-proteins which in turn block adenylyl cyclase activity reducing cAMP (Figure 7) [18]. Pertussis toxin (PTX) inactivates $\mathrm{G}_{\mathrm{i}}$-proteins and blocks downregulation of cAMP (Figure 7) [34]. IBMX, however, increases cAMP levels as a result of phosphodiesterase inhibition (Figure 7). To analyze the critical role of cAMP in opioid receptor activation-induced apoptosis, the BCP-ALL cell line Tanoue was treated with D,L-methadone, doxorubicin, and IBMX or PTX either alone or in different combinations with each other (Figure 5C and 5D). After 96h we found that upregulation of cAMP by IBMX (Figure 5C) as well as blocking downregulation of cAMP by PTX (Figure 5D) strongly reduced the apoptotic rates of combination treatment with D,L-methadone and doxorubicin. In addition, the upregulation of cAMP by IBMX also decreased doxorubicin-induced apoptosis (Figure 5C). These results indicate that the activation of $\mathrm{G}^{\mathrm{i}}$-protein- coupled opioid receptors is essential for the induction of apoptosis which might be regulated via the intracellular cAMP levels.

\section{Inhibition of tumor growth in vivo}

In vitro results demonstrated that D,L-methadone induces apoptosis in several leukemia cell lines and increases the cytotoxicity of doxorubicin. To confirm the clinical relevance of the anti-cancer potential of D,Lmethadone alone or in combination with doxorubicin and to verify the results obtained so far an ALL-xenograft study was undertaken (Figure 6).

For the in vivo study, a patient-derived ALLxenograft model (ALL-SCID6) was used. Its phenotypic and genotypic identity with the original patient sample was proven [28]. The experiment started with subcutaneous inoculation of ALL-SCID6 fragments from an in vivo passage into male NOD/SCID/IL2r $\gamma$ null (NSG) mice. After randomization, D,L-methadone was orally administered after ALL-inoculation with increasing doses. When tumors were palpable, doxorubicin treatment was initiated. D,L-Methadone and doxorubicin treatment led to a significant inhibition of tumor growth at comparable levels (Figure 6). Combination treatment with D,L-
A



B

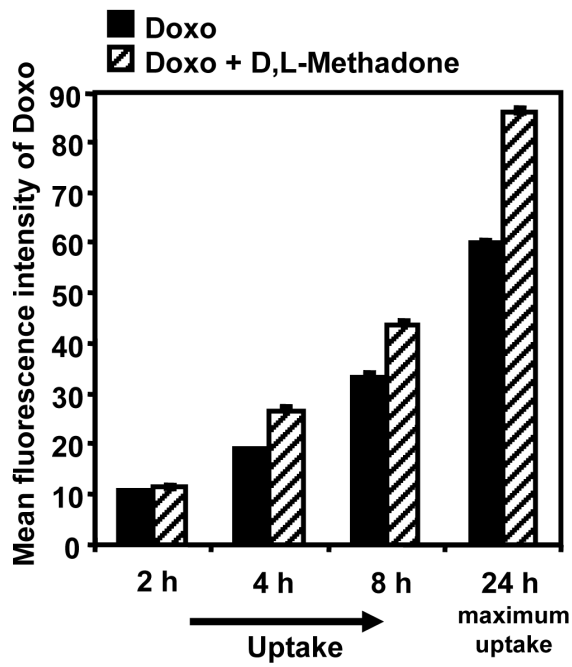

C

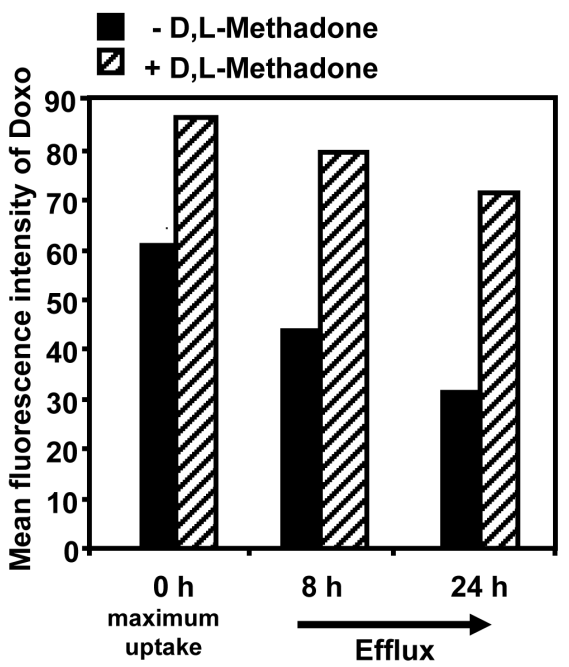

Figure 4: Doxorubicin enhances opioid receptor expression whereas D,L-methadone enhances doxorubicin uptake and inhibits its efflux. (a) Doxorubicin enhances opioid receptor expression on the cells` surface. The BCP-ALL cell line Tanoue was treated for $96 \mathrm{~h}$ with $0.06 \mu \mathrm{g} / \mathrm{mL}$ doxorubicin. After staining of doxorubicin-treated (+ Doxo) and untreated cells (- Doxo) with naloxone-fluoresceine relative fluorescence intensities were determined flowcytometrically. X-fold increase in opioid receptor expression is shown after subtracting the cells autofluorescence (- Doxo) and doxorubicin fluorescence (+ Doxo). (b) D,L-methadone enhances doxorubicin uptake. The BCP-ALL cell line Tanoue was either pre-treated with $0.3 \mu \mathrm{g} / \mathrm{mL}$ doxorubicin (black columns, Doxo) alone or with a combination of doxorubicin and $3 \mu \mathrm{g} / \mathrm{mL}$ D,L-methadone (hatched columns, Doxo + D,L-Methadone) for $2 \mathrm{~h}, 4 \mathrm{~h}, 8 \mathrm{~h}$ and $24 \mathrm{~h}$. Cell uptake was analyzed via doxorubicin fluorescence in cells using flow cytometry after $2 \mathrm{~h}, 4 \mathrm{~h}, 8 \mathrm{~h}$ and $24 \mathrm{~h}$ (maximum uptake). (C) D,LMethadone inhibits doxorubicin efflux. 24h after maximal uptake of doxorubicin (0h, maximum uptake) cells were washed with medium to remove doxorubicin. After washing doxorubicin-treated BCP-ALL cells, BCP-ALL cells were either left untreated (black columns, D,L-Methadone) or treated with $3 \mu \mathrm{g} / \mathrm{mL}$ D,L-methadone (hatched columns, + D,L-Methadone) and incubated for different points in time (8h, 24h). Doxorubicin efflux was analyzed via doxorubicin fluorescence in cells using flow cytometry after $8 \mathrm{~h}$ and $24 \mathrm{~h}$. Values are mean fluorescence intensities +/-SE. 
methadone and doxorubicin had a similar anti-tumor efficacy as D,L-methadone or doxorubicin alone until day 70 (Figure 6). At later time points, the tumor inhibition was longer lasting during the combined treatment of D,Lmethadone and doxorubicin (Figure 6). The therapy was well-tolerated with body weight changes of $-10 \%$ for the combination and $-8 \%$ or $-4 \%$ for the D,L-methadone or doxorubicin treatment, respectively. To analyze D,Lmethadone serum concentrations in mice, $0.5 \mathrm{~h}, 1 \mathrm{~h}$, $4 \mathrm{~h}$ and $24 \mathrm{~h}$ after the last D,L-methadone application, serum was taken and D,L-methadone quantified by mass spectrometry. The serum concentrations of methadone were found between $56 \mathrm{ng} / \mathrm{mL}$ and $230 \mathrm{ng} / \mathrm{mL}$ in the time

A

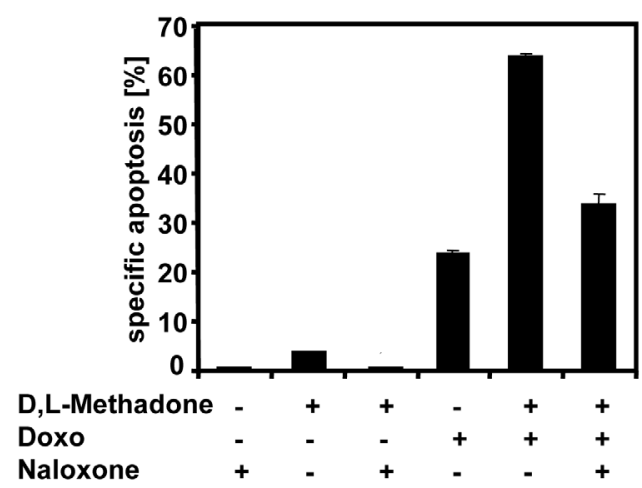

B

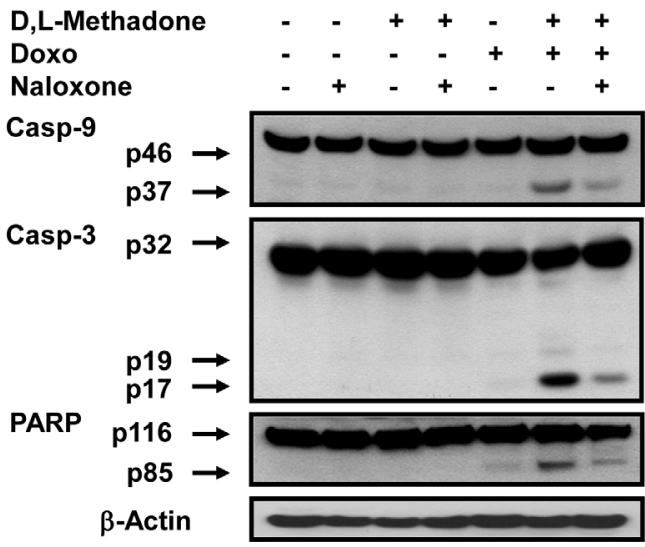

course of $0.5 \mathrm{~h}$ until $4 \mathrm{~h}$ after D,L-methadone application. The serum concentrations of doxorubicin were found between $156 \mathrm{ng} / \mathrm{mL}$ and $198 \mathrm{ng} / \mathrm{mL}$. These results demonstrate that D,L-methadone and the co-treatment using doxorubicin and D,L-methadone significantly inhibited tumor growth in vivo.

\section{DISCUSSION}

ALL is a malignant disorder originating from single B- or T-lymphocyte progenitors [1]. Despite the significant progress made in the overall cure rate, the prognosis of relapsed ALL patients still remains poor [2]


Figure 5: Combination treatment with D,L-Methadone and doxorubicin induced apoptosis depends on opioidreceptor triggering via downregulation of cAMP. (a) Inhibition of opioid-receptor triggering inhibits apoptosis induction mediated by combination treatment with D,L-methadone and doxorubicin. The BCP-ALL cell line Tanoue was incubated with $60 \mu \mathrm{g} / \mathrm{mL}$ naloxone (Naloxone), $3 \mu \mathrm{g} / \mathrm{mL}$ D,L-methadone (D,L-Methadone) and $0.06 \mu \mathrm{g} / \mathrm{mL}$ doxorubicin (Doxo) alone or in different combinations as indicated. After 96h, apoptotic cells were measured by FSC/SSC-analysis. (b) Inhibition of opioid-receptor triggering inhibits caspase activation mediated by combination treatment with D,L-methadone and doxorubicin. Tanoue cells were incubated with $60 \mu \mathrm{g} / \mathrm{mL}$ naloxone (Naloxone), $3 \mu \mathrm{g} / \mathrm{mL}$ D,L-methadone (D,L-Methadone) and $0.06 \mu \mathrm{g} / \mathrm{mL}$ doxorubicin (Doxo) alone or in different combinations as indicated. Western blot analyses for caspase-9, caspase-3 and PARP were performed after 96h of incubation. The active fragment of caspase-9 was detected at $\sim 37 \mathrm{kDa}$, of caspase-3 at $\sim 19 \mathrm{kDa}$ and $\sim 17 \mathrm{kDa}$ and PARP cleavage at $\sim 85 \mathrm{kDa}$. Equal protein loading was controlled by anti$\beta$-actin antibody. (c) Increasing cAMP levels via repression of phosphodiesterase activity inhibits apoptosis. Tanoue cells were incubated for $96 \mathrm{~h}$ with $200 \mu \mathrm{M}$ 3-isobutyl-1-methylxanthine (IBMX), $3 \mu \mathrm{g} / \mathrm{mL}$ D,L-methadone (D,L-Methadone) and 0.06 $\mu \mathrm{g} / \mathrm{mL}$ doxorubicin (Doxo) alone or in different combinations as indicated. (d) Uncoupling $\mathrm{G}_{\mathrm{i}}$-proteins from opioid receptors inhibits apoptosis by preventing inhibition of adenylyl cyclases. Tanoue cells were incubated with $200 \mathrm{ng} / \mathrm{mL}$ pertussis toxin (PTX), $3 \mu \mathrm{g} / \mathrm{mL}$ D,L-methadone (D,L-Methadone) and $0.06 \mu \mathrm{g} / \mathrm{mL}$ doxorubicin (Doxo) alone or in different combinations as indicated. After $96 \mathrm{~h}$, the percentages of apoptotic cells were measured by FSC/SSC-analysis. The percentages of specific apoptosis was calculated as described in Figure 1B. Columns, mean of triplicates; bars, $\mathrm{SD}<10 \%$. 
as cellular resistances to anti-cancer drugs occur $[3,6,7$, 35-37]. Hence, it is important to find alternate therapies overcoming resistances. Recent studies demonstrate that $\mathrm{D}, \mathrm{L}-\mathrm{methadone}$ kills leukemia cells in vitro and inhibits cell proliferation of lung cancer cells [22, 23, 25-27]. Additionally, D,L-methadone abrogates chemoresistance in leukemia cell lines without affecting normal lymphocytes [25]. Co-treatment with D,L-methadone and an anti-Bcl-2-agent leads to synergistic effects in leukemia cells [23]. However, the underlying mechanisms how D,Lmethadone leads to apoptosis induction are not understood. Additionally, the tumor growth inhibitory potential of D,Lmethadone has not been demonstrated in vivo nor have the synergistic effects in cell killing with conventionally administered chemotherapeutics been analyzed. In this study, we provide evidence that D,L-methadone induces apoptosis, activates caspases and increases doxorubicintriggered cell death in leukemia cells after opioid-receptor activation inducing the downregulation of cAMP. In addition, we demonstrate first that D,L-methadone can strongly reduce tumor growth of ALL in vivo.

Methadone binds as agonist to mu-opioid receptors. We found that D,L-methadone kills xenograft-derived ALL cells expressing high levels of opioid receptors. In contrast, D,L-methadone induces cell death only slightly in xenograft-derived ALL cells and cell lines expressing moderate opioid receptor amounts indicating that D,Lmethadone-induced apoptosis depends on critical levels

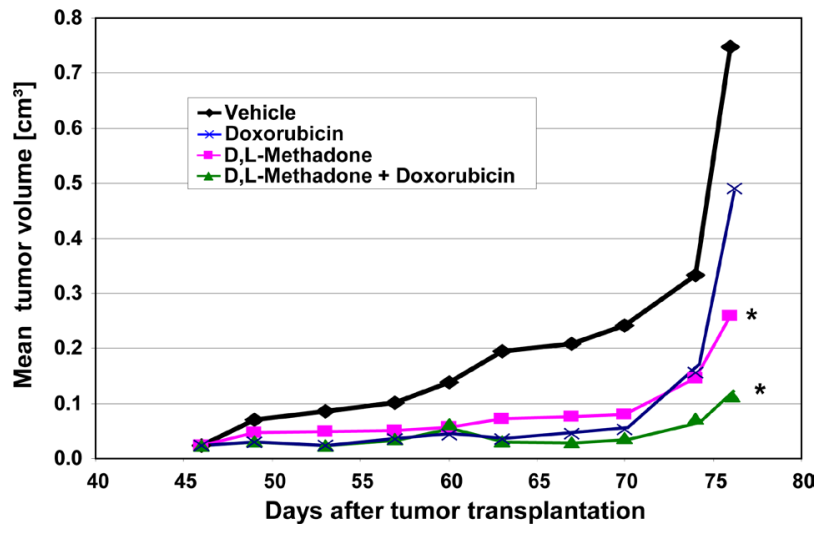

Figure 6: Opioid receptor activation by D,Lmethadone inhibits growth of leukemia xenografts and increases doxorubicin sensitivity in vivo. Fragments of an in vivo passage of a patient-derived T-ALL (ALL-SCID6, see also Figure 1) were transplanted into male NSG mice. Mice were treated with D,L-methadone alone $(n=8$, orally day 1-76, D,L-Methadone), with doxorubicin alone ( $\mathrm{n}=8$, i.v. day $46,53,60,76$, Doxorubicin) or with a combination treatment with D,L-methadone and doxorubicin $(n=8, D, L-M e t h a d o n e+$ Doxorubicin). D,L-Methadone was used in weekly increasing doses from 20 up to $120 \mathrm{mg} / \mathrm{kg} /$ day and doxorubicin in a dose of $3 \mathrm{mg} / \mathrm{kg}$. As control group xenografted mice were treated i.v. with $10 \%$ Tween 80 in saline ( $\mathrm{n}=8$, Vehicle). For 76 days after transplantation all mice were monitored for tumor growth, body weight and health condition. *significant to vehicle $(\mathrm{p}<0.05$, Mann-Whitney U test). of opioid receptor expression in leukemia cells.

Combination treatment may prove to be advantageous in malignancies that still partially respond to either treatment alone as different therapeutics are known to interact with each other amplifying weaker death signals $[2,5,35,38-43]$. Combination treatment with $\mathrm{D}, \mathrm{L}-\mathrm{methadone}$ and doxorubicin enhances the antitumor efficacy of both agents synergistically in BCPALL cells expressing moderate levels of opioid-receptors and increases caspase activation playing a critical role in apoptosis induction in sensitive and resistant cancer cells [6]. Furthermore, the downregulation of the antiapoptotic proteins XIAP and Bcl-xL involved in the occurrence of resistances in many malignancies like ALL or NHL [44-48] is markedly enhanced. These suggest that combination treatment of D,L-methadone and doxorubicin increases apoptosis induction, caspase activation and downregulation of XIAP and Bcl- $\mathrm{x}_{\mathrm{L}}$ synergistically.

Resistance to conventional chemotherapeutic drugs is a limiting factor of therapies whereby multidrug resistances resulting from overexpression of drug transporters such as P-gp are well-characterized [33, 49]. While in healthy cells the P-gp expression belongs to the normal cellular defense system, in cancer cells the overexpression of P-gp correlates with decreased survival and poor outcome $[50,51]$. D,L-Methadone could be shown to be a substrate of P-gp [33,49] inhibiting its action [30-32]. We found that co-treatment of doxorubicin with D,L-methadone enhances doxorubicin uptake and furthermore inhibits doxorubicin-efflux out of leukemia cells, suggesting that D,L-methadone sensitizes leukemia cells for doxorubicin-induced apoptosis by increasing concentrations of doxorubicin within the cells.

Posovsky et al found that chemotherapeutic drugs like doxorubicin sensitize BCP-ALL cells expressing low amounts of CD95 receptors on their surface for CD95mediated apoptosis and caspase activation by upregulating CD95 receptors [29]. The enhanced toxicity of the combination treatment of D,L-methadone and doxorubicin is associated with an increased expression of opioidreceptors after doxorubicin treatment. Therefore, D,Lmethadone can bind in higher amounts to cells co-treated with doxorubicin. These results indicate that the enhanced toxicity in the combination treatment with D,L-methadone and doxorubicin is associated with the upregulation of opioid-receptor expression mediated by doxorubicin and furthermore with an increased uptake and decreased efflux of doxorubicin mediated by D,L-methadone.

Opioid receptors signal by catalyzing liganddependent nucleotide exchange on $\mathrm{G}_{\mathrm{i}}$, thereby inhibiting adenylyl cyclase and modulating N-type calcium channels as well as G-protein-gated inwardly rectifying potassium (GIRK) channels leading to changes in cell signaling (Figure 7) [52]. The dependence of apoptosis induction on opioid-receptor triggering is underlined by their inhibition. Blocking opioid-receptor signaling with the 
opioid receptor antagonist naloxone inhibited combination treatment with D,L-methadone and doxorubicin-induced apoptosis and caspase activation in a high rate, suggesting that opioid-receptor triggering by D,L-methadone is involved in apoptosis induction and caspase activation (Figure 7). Maneckjee et al showed for human lung cancer cells that the opioid receptor antagonist naloxone in combination with methadone increased cAMP levels suggesting that inhibition of opioid receptor activation by methadone rises cAMP [26]. The second messenger cAMP is involved in a number of physiologic functions in response to various extracellular stimuli controlling cell proliferation, differentiation, and apoptosis whereby it can either inhibit or stimulate apoptosis dependent on the respective cell type $[20,53]$. For various tumor cells like pancreatic or leukemia cells stimulated with different agents, it could be demonstrated that cAMP elevation is associated with impaired cell death [54-56]. Responsible for this protective action of cAMP against apoptosis is among others the synthesis of anti-apoptotic proteins, inactivation of pro-apoptotic proteins, and activation of PI3K-dependent Akt [57-59]. In the AML cell line HL60 , for instance, PKA inhibitors impair the cytoprotective effect from cAMP on the cells [60]. Activation of cAMP plays also a critical role in inhibiting DNA-damage- and doxorubicin-induced apoptosis via p53 dephosphorylation $[15,16]$ and furthermore by NF- $\kappa \mathrm{B}$ activation [61]. Opioid receptor stimulation activates inhibitory Gi-proteins which in turn block adenylyl cyclase activity reducing cAMP [17]. We found that D,L-methadone induced apoptosis and activated caspases by triggering opioid receptors via downregulation of cAMP. Blocking the activation of opioid receptors by naloxone or inhibiting $\mathrm{G}_{\mathrm{i}}$ proteins with PTX increased cAMP and strongly reduced apoptotic signaling triggered by the co-treatment with D,L-methadone and doxorubicin. In addition, upregulation of cAMP by inhibition of cAMP phosphodiesterases using IBMX reduced the cytoxicity of the combination treatment using D,L-methadone and doxorubicin in human BCP-ALL cells. Furthermore, opioid receptor triggering by D,L-methadone inhibits proliferation and leads to accumulation of leukemia cells in G1-phase which was previously observed [25]. These results suggest that opioid receptor activation by $\mathrm{D}, \mathrm{L}-\mathrm{meth}$ adone triggers downregulation of cAMP mediating caspase activation and apoptosis induction in leukemia cells (Figure 7) and sensitizes leukemia cells for doxorubicin treatment.

In vitro results have shown that $\mathrm{D}, \mathrm{L}-$ methadone can induce apoptosis in several leukemia cell lines [23, 25]. In the current study, we could verify the clinical relevance with patient-derived ALL cells ex vivo and we provide the first evidence that D,L-methadone as monotherapy or in combination with doxorubicin leads to a strong tumor growth inhibition in a patient-derived leukemia model in vivo. Both the anti-leukemic efficacy and the side effects of D,L-methadone alone or in combination with doxorubicin were comparable with those of doxorubicin alone. Anyhow, a longer lasting growth inhibition could be proven upon combination treatment. The serum concentrations of methadone in mice correlated with

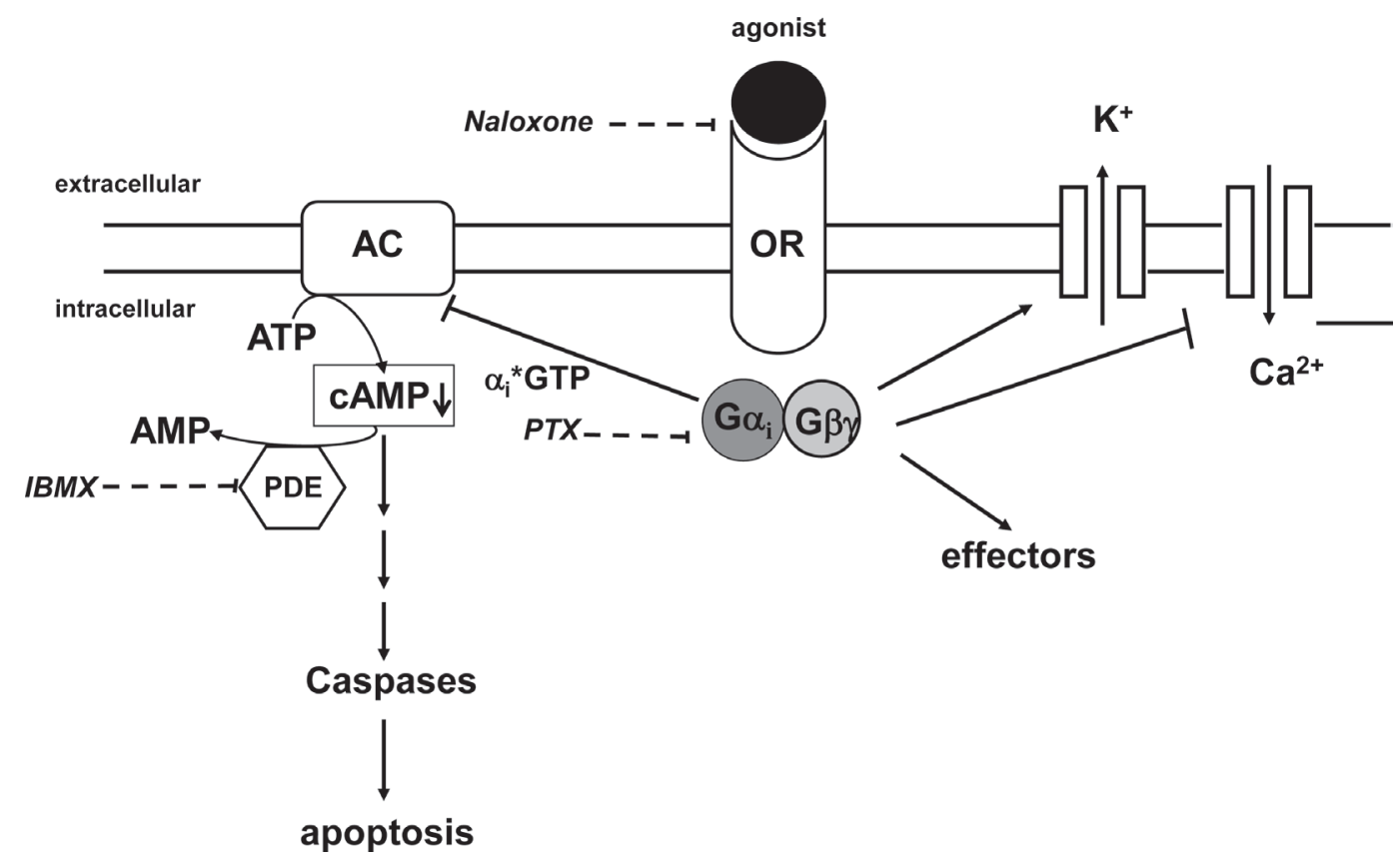

Figure 7: Opioid receptor signaling. Stimulation of opioid receptors (OR) by agonists like D,L-methadone leads to an activation of the inhibitory $\mathrm{G}_{\mathrm{i}}$-protein. The alpha $\mathrm{i}_{\mathrm{i}}$-subunit inactivates adenylyl cyclases (AC) resulting in a reduction of cAMP levels within the cell which in turn leads to apoptosis. Naloxone as opioid receptor antagonist inhibits competitively opioid receptors. PTX (pertussis toxin) inactivates $\mathrm{G}_{\mathrm{i}}$-proteins and blocks downregulation of cAMP. IBMX (3-isobutyl-1-methylxanthine) inhibits phosphodiesterase activity (PDE) and increases cAMP levels. 
the concentrations showing in vitro cytotoxicity. This indicates that $\mathrm{D}, \mathrm{L}-\mathrm{methadone}$ may have a promising therapeutic potential in leukemia therapy and could improve therapeutic success of conventional therapies.

Taken together, our results demonstrate that D,L-methadone induces apoptosis, mediates caspase activation and sensitizes leukemia cells for doxorubicin treatment through opioid receptor activation triggering the downregulation of cAMP (Figure 7). D,L-methadoneinduced cell death depends on critical levels of opioid receptor expression which can be increased by doxorubicin. Additionally, D,L-methadone increases doxorubicin influx and hampers its efflux in leukemia cells. Furthermore, we could demonstrate for the first time that D,L-methadone alone or in combination with doxorubicin leads to a significant tumor growth inhibition in a patient-derived leukemia model in vivo. These results have important implications for the development of novel strategies in cancer therapy especially when conventional therapies are less effective.

\section{METHODS}

\section{Drugs and reagents}

For the in vitro experiments, D,L-methadone hydrochloride (D,L-methadone) and doxorubicin were purchased from Sigma (Taufkirchen, Germany), naloxone from Fagron GmbH\&Co. KG (Barsbüttel, Germany), and pertussis toxin (PTX) from Calbiochem (Nottingham, UK). Prior to each experiment these substances were freshly dissolved in sterile distilled water to ensure the constant quality of the preparations. 3-Isobutyl-1methylxanthine (IBMX, Sigma) was freshly dissolved in $0.01 \mathrm{~N} \mathrm{NaOH}$.

For in vivo application, we used D,L-methadone (Methaddict, Hexal, Germany) as 5mg tablets purchased from the local pharmacy. The tablets were pulverized and solubilized freshly before use in 10\% Tween 80 in saline. Doxorubicin (Hexal) was purchased as injection solution $(5 \mathrm{mg} / \mathrm{mL})$ and diluted freshly with saline to the appropriate concentrations.

\section{Cell lines}

The human B-cell leukemia (BCP-ALL) cell lines Tanoue, Reh and Nalm6 were obtained from the DSMZ (Braunschweig, Germany) and cultured in RPMI 1640 (Invitrogen) containing 10\% FCS (Lonza, Verviers, Belgium), 1mmol/L glutamine (Invitrogen), 1\% penicillin/ streptomycin (Invitrogen), 25mmol/L HEPES (Biochrom) at $37^{\circ} \mathrm{C}, 95 \%$ air $/ 5 \% \mathrm{CO} 2$. In experimental settings, the leukemia cells were seeded in a density of 100000 cells/ $\mathrm{mL}$.

\section{Serum concentrations of methadone}

Determination of methadone in serum samples was carried out after liquid/liquid extraction using a mass spectrometer equipped with a gas chromatograph (GC/ MS). As internal standard d9-methadone was added. The mass selective detector was operated in electron impact mode. Data were acquired in the selected-ion monitoring mode. The analytes were identified with the following masses $\mathrm{m} / \mathrm{z}$ 294, 223, 72 (target ion) for methadone and $\mathrm{m} / \mathrm{z} 303,226$, and 78 for $\mathrm{d}_{9}$-methadone with a limit of detection of $0.8 \mathrm{ng} / \mathrm{mL}$ and a limit of quantification of $1.2 \mathrm{ng} / \mathrm{mL}$.

\section{Serum concentrations of doxorubicin}

Determination of doxorubicin and its main metabolites in serum were performed as described previously $[62,63]$. Using this validated method, the quantification of doxorubicin, doxorubicinol, and 7-deoxydoxorubicinolon was possible with a LLQ of $0.2 \mathrm{ng} / \mathrm{mL}$.

\section{Patient-derived ALL xenografts}

For in vivo use the ALL-SCID6 model was chosen. Fragments from in vivo passaged tumors were transplanted subcutaneously at day 0 to 32 male NOD/ SCID/IL2r $\gamma$ null (NSG) mice. After randomization oral treatment (by gavage) with D,L-methadone was initiated one day later and performed daily until the end of the experiment with increasing doses: $1^{\text {st }}$ week $20 \mathrm{mg} / \mathrm{kg} / \mathrm{d}$, $2^{\text {nd }}$ week $30 \mathrm{mg} / \mathrm{kg} / \mathrm{d}, 3{ }^{\text {rd }}$ week $40 \mathrm{mg} / \mathrm{kg} / \mathrm{d}, 4^{\text {th }}$ week $60 \mathrm{mg} /$ $\mathrm{kg} / \mathrm{d}, 5^{\text {th }}-10^{\text {th }}$ week $2 \times 60 \mathrm{mg} / \mathrm{kg} / \mathrm{inj}$. The dose adaptation was necessary to avoid toxic deaths because of an overdosage of D,L-methadone. The maximum tolerated dose of D,Lmethadone in the employed mouse strain is $2 \times 60 \mathrm{mg} / \mathrm{kg} /$ inj. At day 46, 53, 60 and 76 doxorubicin $(3 \mathrm{mg} / \mathrm{kg})$ was administered i.v. Tumor size was measured twice weekly at two dimensions and tumor volumes were calculated according to the formula (length $\mathrm{x}$ width ${ }^{2}$ )/2. Mean tumor volumes and standard deviations were calculated per group. Treated to control values (T/C) in percent were calculated by relating mean tumor volumes of each group at each measurement day to the controls. Individual body weight was determined twice per week as parameter for tolerability. Body weight changes [\%] were calculated by relating the mean values of each group to the first measurement day.

Serum from D,L-methadone treated mice was taken $0.5,1,4$ and 24 hours after last D,L-methadone treatment at day 76 , respectively, and stored at $-20^{\circ} \mathrm{C}$ until the determination of methadone concentration. Mice were sacrificed at day 77 for ethical reasons.

For the in vitro investigations, cell suspensions 
of human xenograft-derived ALL cells from patients with T-cell (ALL-SCID6, ALL-SCID3), B-cell (ALLSCID7) and B-cell precursor (BCP, pre-B-ALL-SCID) acute leukemia were gained and cultivated in vitro and were phenotypically and genotypically characterized as described [28]. All animal experiments were approved by the local responsible authorities (LaGeSo Berlin) and performed according to the guidelines for animal welfare in oncological experiments [64].

\section{Flow cytometric assay for determination of cell surface opioid-receptors}

Cells were washed in PBS supplemented with $1 \% \mathrm{FCS}$, centrifuged and resuspended in PBS/1\% FCS containing naloxone-fluoresceine $(0.05 \mathrm{mM}$, Invitrogen) [65]. After $30 \mathrm{~min}$ of incubation at RT, the cells were washed, centrifuged and resuspended in icecold PBS/1\% FCS. Flow cytometry analysis was performed using FACSCalibur (BD, Heidelberg, Germany).

\section{Induction of apoptosis and determination of cell survival}

ALL cells were treated with D,L-methadone $(\leq 3 \mu \mathrm{g} /$ $\mathrm{mL}$ therapeutic plasma concentration) alone or in addition to doxorubicin in $175 \mathrm{~cm}^{2}$ flasks or 96 -well plates. Further experiments were performed simultaneously after addition of $60 \mu \mathrm{g} / \mathrm{mL}$ naloxone, $200 \mu \mathrm{M}$ IBMX (3-isobutyl-1methylxanthine) or 200ng/mL PTX (pertussis toxin). After different points in time, apoptosis rates were measured by flow cytometry [66, 67]. To determine apoptosis, cells were lysed with Nicoletti-buffer containing sodium citrate $(0.1 \%)$, Triton X $100(0.1 \%)$ and propidium iodide $(50 \mu \mathrm{g} / \mathrm{mL})$ as described by Nicoletti [67]. Apoptotic cells were determined by hypodiploid DNA (subG1) or forward scatter/side scatter analysis [66]. Cell survival was determined by forward scatter/side scatter analysis using flow cytometry [66]. The percentage of specific apoptosis was calculated as follows: $100 \mathrm{x}$ [experimental dead cells (\%) - spontaneous dead cells in medium (\%)] / [100\% -spontaneous dead cells in medium (\%)]. The spontaneous dead cells were in the range of 5 to $10 \%$ using cell lines. The spontaneous dead of untreated human xenograftderived ALL cells was less than $35 \%$ at $24 \mathrm{~h}$ and $48 \mathrm{~h}$.

\section{General caspase inhibition by zVAD.fmk}

For inhibition of apoptosis, leukemia cells were treated with the pancaspase inhibitor zVAD.fmk (z-ValAla-D,L-Asp-fluoromethylketone; Bachem, Bubendorf, Germany) as described [68, 69]. 50 $\mu \mathrm{M}$ zVAD.fmk was added to the cells $1 \mathrm{~h}$ before stimulation with D,Lmethadone and doxorubicin. The percentage of apoptotic cells was determined by $\mathrm{FSC} / \mathrm{SSC}$ analysis via flow cytometry [66].

\section{Western blot analysis}

Western blot analyses were performed as described [37, 68-70]. Whole cell lysates were immunodetected for PARP, caspase-3, caspase-9, XIAP, Bcl- $\mathrm{x}_{\mathrm{L}}$ and $\beta$-actin using rabbit-anti-PARP-polyclonal-antibody (1:5000, Roche), anti-XIAP-monoclonal-antibody (both 1:1000, BD Transduction Laboratories, Heidelberg, Germany), mouse-anti-caspase-3-monoclonal-antibody, rabbitanti-caspase-9-polyclonal-antibody (both 1:1000, Cell Signaling, Boston, MA, USA) rabbit-anti-Bcl- $\mathrm{x}_{\mathrm{L}}$ polyclonal-antibody (1:1000, Santa-Cruz, Heidelberg, Germany) and mouse-anti-ß-actin-monoclonal-antibody (1:5000, Sigma). As secondary antibodies peroxidaseconjugated-goat-anti-mouse IgG or peroxidaseconjugated-goat-anti-rabbit IgG (1:5000, Santa-Cruz) were used for the enhanced chemoluminescence system (ECL, Amersham-Pharmacia, Freiburg, Germany). Equal protein loading was controlled by $\beta$-actin detection.

\section{Analysis of doxorubicin uptake and efflux}

For analysis of doxorubicin uptake, the BCPleukemia cell line Tanoue was seeded in a density of 100000 cells $/ \mathrm{mL}$ in $175 \mathrm{~cm}^{2}$ flasks and was either left untreated or incubated with $0.3 \mu \mathrm{g} / \mathrm{mL}$ doxorubicin or a combination of $0.3 \mu \mathrm{g} / \mathrm{mL}$ doxorubicin and $3 \mu \mathrm{g} / \mathrm{mL}$ D, Lmethadone. After different time point in time cells were washed and the relative doxorubicin uptake in cells was analyzed using flow cytometry.

For analysis of doxorubicin efflux, cells were washed to remove doxorubicin from medium after incubation for $24 \mathrm{~h}$ (maximum uptake). Next, cells were incubated with fresh medium without doxorubicin or fresh medium containing $3 \mu \mathrm{g} / \mathrm{mL}$ D, L-methadone without doxorubicin to measure doxorubicin efflux. After different time points, cells were harvested, washed and relative doxorubicin content in leukemia cells was analyzed using flow cytometry.

\section{ACKNOWLEDGEMENTS}

We want to thank Gabriele Aggeler and Petra Hornischer for superior technical assistance, Britta Büttner and Svetlana Gromova for excellent support in animal experiments.

The authors declare that they have none conflict of interest.

\section{REFERENCES}

1. Rabin KR and Poplack DG. Management strategies in acute 
lymphoblastic leukemia. Oncology (Williston Park). 2011; 25(4):328-335.

2. Faderl S, O’Brien S, Pui CH, Stock W, Wetzler M, Hoelzer D and Kantarjian HM. Adult acute lymphoblastic leukemia: concepts and strategies. Cancer. 2010; 116(5):1165-1176.

3. Pui CH, Robison LL and Look AT. Acute lymphoblastic leukaemia. Lancet. 2008; 371(9617):1030-1043.

4. Meyer LH, Eckhoff SM, Queudeville M, Kraus JM, Giordan M, Stursberg J, Zangrando A, Vendramini E, Moricke A, Zimmermann M, Schrauder A, Lahr G, Holzmann K, Schrappe M, Basso G, Stahnke K, et al. Early relapse in all is identified by time to leukemia in NOD/SCID mice and is characterized by a gene signature involving survival pathways. Cancer Cell. 2011; 19(2):206-217.

5. Bassan R and Hoelzer D. Modern therapy of acute lymphoblastic leukemia. J Clin Oncol. 2011; 29(5):532543.

6. Fulda S. Tumor resistance to apoptosis. Int J Cancer. 2009; 124(3):511-515.

7. Kostanova-Poliakova D and Sabova L. Anti-apoptotic proteins-targets for chemosensitization of tumor cells and cancer treatment. Neoplasma. 2005; 52(6):441-449.

8. Friesen C, Herr I, Krammer PH and Debatin KM. Involvement of the CD95 (APO-1/FAS) receptor/ligand system in drug-induced apoptosis in leukemia cells. Nat Med. 1996; 2(5):574-577.

9. Kroemer G, Galluzzi L, Vandenabeele P, Abrams J, Alnemri ES, Baehrecke EH, Blagosklonny MV, ElDeiry WS, Golstein P, Green DR, Hengartner M, Knight RA, Kumar S, Lipton SA, Malorni W, Nunez G, et al. Classification of cell death: recommendations of the Nomenclature Committee on Cell Death 2009. Cell Death Differ. 2009; 16(1):3-11.

10. Timmer JC and Salvesen GS. Caspase substrates. Cell Death Differ. 2007; 14(1):66-72.

11. Fulda S. Therapeutic opportunities for counteracting apoptosis resistance in childhood leukaemia. Br J Haematol. 2009; 145(4):441-454.

12. Fulda S. Cell death in hematological tumors. Apoptosis. 2009; 14(4):409-423.

13. Muppani N, Nyman U and Joseph B. TAp73alpha protects small cell lung carcinoma cells from caspase-2 induced mitochondrial mediated apoptotic cell death. Oncotarget. 2011; 2(12):1145-1154.

14. Ola MS, Nawaz M and Ahsan H. Role of Bcl-2 family proteins and caspases in the regulation of apoptosis. Mol Cell Biochem. 2011; 351(1-2):41-58.

15. Naderi EH, Findley HW, Ruud E, Blomhoff HK and Naderi $\mathrm{S}$. Activation of cAMP signaling inhibits DNA damageinduced apoptosis in BCP-ALL cells through abrogation of p53 accumulation. Blood. 2009; 114(3):608-618.

16. Safa M, Kazemi A, Zand H, Azarkeivan A, Zaker F and Hayat P. Inhibitory role of cAMP on doxorubicin-induced apoptosis in pre-B ALL cells through dephosphorylation of p53 serine residues. Apoptosis. 2010; 15(2):196-203.

17. Jordan B and Devi LA. Molecular mechanisms of opioid receptor signal transduction. Br J Anaesth. 1998; 81(1):1219.

18. Law PY, Wong YH and Loh HH. Molecular mechanisms and regulation of opioid receptor signaling. Annu Rev Pharmacol Toxicol. 2000; 40:389-430.

19. Standifer KM and Pasternak GW. G proteins and opioid receptor-mediated signalling. Cell Signal. 1997; 9(3-4):237248.

20. Insel PA, Murray F, Yokoyama U, Romano S, Yun H, Brown L, Snead A, Lu D and Aroonsakool N. cAMP and Epac in the regulation of tissue fibrosis. Br J Pharmacol. 2012; 166(2):447-456.

21. Fredheim OM, Moksnes K, Borchgrevink PC, Kaasa S and Dale O. Clinical pharmacology of methadone for pain. Acta Anaesthesiol Scand. 2008; 52(7):879-889.

22. Maneckjee R and Minna JD. Opioid and nicotine receptors affect growth regulation of human lung cancer cell lines. Proc Natl Acad Sci U S A. 1990; 87(9):3294-3298.

23. Singh A, Jayanthan A, Farran A, Elwi AN, Kim SW, Farran $\mathrm{P}$ and Narendran A. Induction of apoptosis in pediatric acute lymphoblastic leukemia (ALL) cells by the therapeutic opioid methadone and effective synergy with Bcl-2 inhibition. Leuk Res. 2011; 35(12):1649-1657.

24. Tegeder I and Geisslinger G. Opioids as modulators of cell death and survival--unraveling mechanisms and revealing new indications. Pharmacol Rev. 2004; 56(3):351-369.

25. Friesen C, Roscher M, Alt A and Miltner E. Methadone, commonly used as maintenance medication for outpatient treatment of opioid dependence, kills leukemia cells and overcomes chemoresistance. Cancer Res. 2008; 68(15):6059-6064.

26. Maneckjee R and Minna JD. Nonconventional opioid binding sites mediate growth inhibitory effects of methadone on human lung cancer cells. Proc Natl Acad Sci U S A. 1992; 89(4):1169-1173.

27. Maneckjee R and Minna JD. Opioids induce while nicotine suppresses apoptosis in human lung cancer cells. Cell Growth Differ. 1994; 5(10):1033-1040.

28. Borgmann A, Baldy C, von Stackelberg A, Beyermann B, Fichtner I, Nurnberg P and Henze G. Childhood all blasts retain phenotypic and genotypic characteristics upon longterm serial passage in NOD/SCID mice. Pediatr Hematol Oncol. 2000; 17(8):635-650.

29. Posovszky C, Friesen C, Herr I and Debatin KM. Chemotherapeutic drugs sensitize pre-B ALL cells for CD95- and cytotoxic T-lymphocyte-mediated apoptosis. Leukemia. 1999; 13(3):400-409.

30. Bouer R, Barthe L, Philibert C, Tournaire C, Woodley J and Houin G. The roles of P-glycoprotein and intracellular metabolism in the intestinal absorption of methadone: in vitro studies using the rat everted intestinal sac. Fundam Clin Pharmacol. 1999; 13(4):494-500. 
31. Callaghan R and Riordan JR. Synthetic and natural opiates interact with P-glycoprotein in multidrug-resistant cells. J Biol Chem. 1993; 268(21):16059-16064.

32. Crettol S, Digon P, Golay KP, Brawand M and Eap CB. In vitro P-glycoprotein-mediated transport of (R)-, (S), (R,S)-methadone, LAAM and their main metabolites. Pharmacology. 2007; 80(4):304-311.

33. Shen F, Chu S, Bence AK, Bailey B, Xue X, Erickson PA, Montrose MH, Beck WT and Erickson LC. Quantitation of doxorubicin uptake, efflux, and modulation of multidrug resistance (MDR) in MDR human cancer cells. J Pharmacol Exp Ther. 2008; 324(1):95-102.

34. Law PY, Louie AK and Loh HH. Effect of pertussis toxin treatment on the down-regulation of opiate receptors in neuroblastoma X glioma NG108-15 hybrid cells. J Biol Chem. 1985; 260(27):14818-14823.

35. Martelli AM, Chiarini F, Evangelisti C, Cappellini A, Buontempo F, Bressanin D, Fini M and McCubrey JA. Two hits are better than one: targeting both phosphatidylinositol 3-kinase and mammalian target of rapamycin as a therapeutic strategy for acute leukemia treatment. Oncotarget. 2012; 3(4):371-394.

36. Qiao M, Shi Q and Pardee AB. The pursuit of oncotargets through understanding defective cell regulation. Oncotarget. 2010; 1(7):544-551.

37. Friesen C, Kiess $\mathrm{Y}$ and Debatin K-M. A critical role of glutathione in determining apoptosis sensitivity and resistance in leukemia cells. Cell Death Differ. 2004; 11:7385.

38. Burger JA and Hoellenriegel J. Phosphoinositide 3'-kinase delta: turning off BCR signaling in Chronic Lymphocytic Leukemia. Oncotarget. 2011; 2(10):737-738.

39. Vakana E and Platanias LC. AMPK in BCR-ABL expressing leukemias. Regulatory effects and therapeutic implications. Oncotarget. 2011; 2(12):1322-1328.

40. Posthumadeboer J, van Egmond PW, Helder MN, de Menezes RX, Cleton-Jansen AM, Belien JA, Verheul HM, van Royen BJ, Kaspers GJ and van Beusechem VW. Targeting JNK-interacting-protein-1 (JIP1) sensitises osteosarcoma to doxorubicin. Oncotarget. 2012; 3(10):1169-1181.

41. Neznanov N, Komarov AP, Neznanova L, Stanhope-Baker $\mathrm{P}$ and Gudkov AV. Proteotoxic stress targeted therapy (PSTT): induction of protein misfolding enhances the antitumor effect of the proteasome inhibitor bortezomib. Oncotarget. 2011; 2(3):209-221.

42. Azmi AS, Banerjee S, Ali S, Wang Z, Bao B, Beck FW, Maitah M, Choi M, Shields TF, Philip PA, Sarkar FH and Mohammad RM. Network modeling of MDM2 inhibitoroxaliplatin combination reveals biological synergy in wtp53 solid tumors. Oncotarget. 2011; 2(5):378-392.

43. Chiarini F, Lonetti A, Teti G, Orsini E, Bressanin D, Cappellini A, Ricci F, Tazzari PL, Ognibene A, Falconi M, Pagliaro P, Iacobucci I, Martinelli G, Amadori S, McCubrey
JA and Martelli AM. A combination of temsirolimus, an allosteric mTOR inhibitor, with clofarabine as a new therapeutic option for patients with acute myeloid leukemia. Oncotarget. 2012; 3(12):1615-1628.

44. Addeo R, Caraglia M, Baldi A, D'Angelo V, Casale F, Crisci S, Abbruzzese A, Vincenze B, Campioni M, Di Tullio MT and Indolfi P. Prognostic role of bcl-xL and p53 in childhood acute lymphoblastic leukemia (ALL). Cancer Biol Ther. 2005; 4(1):32-38.

45. Casale F, Addeo R, D'Angelo V, Indolfi P, Poggi V, Morgera C, Crisci S and Di Tullio MT. Determination of the in vivo effects of prednisone on Bcl-2 family protein expression in childhood acute lymphoblastic leukemia. Int J Oncol. 2003; 22(1):123-128.

46. Hundsdoerfer P, Dietrich I, Schmelz K, Eckert C and Henze G. XIAP expression is post-transcriptionally upregulated in childhood ALL and is associated with glucocorticoid response in T-cell ALL. Pediatr Blood Cancer. 2010; 55(2):260-266.

47. Kuppers R, Klein U, Schwering I, Distler V, Brauninger A, Cattoretti G, Tu Y, Stolovitzky GA, Califano A, Hansmann ML and Dalla-Favera R. Identification of Hodgkin and Reed-Sternberg cell-specific genes by gene expression profiling. J Clin Invest. 2003; 111(4):529-537.

48. Muris JJ, Cillessen SA, Vos W, van Houdt IS, Kummer JA, van Krieken JH, Jiwa NM, Jansen PM, Kluin-Nelemans HC, Ossenkoppele GJ, Gundy C, Meijer CJ and Oudejans JJ. Immunohistochemical profiling of caspase signaling pathways predicts clinical response to chemotherapy in primary nodal diffuse large B-cell lymphomas. Blood. 2005; 105(7):2916-2923.

49. Broxterman HJ, Giaccone G and Lankelma J. Multidrug resistance proteins and other drug transport-related resistance to natural product agents. Curr Opin Oncol. 1995; 7(6):532-540.

50. Diestra JE, Condom E, Del Muro XG, Scheffer GL, Perez J, Zurita AJ, Munoz-Segui J, Vigues F, Scheper RJ, Capella G, Germa-Lluch JR and Izquierdo MA. Expression of multidrug resistance proteins P-glycoprotein, multidrug resistance protein 1 , breast cancer resistance protein and lung resistance related protein in locally advanced bladder cancer treated with neoadjuvant chemotherapy: biological and clinical implications. J Urol. 2003; 170(4 Pt 1):13831387.

51. Leonessa F and Clarke R. ATP binding cassette transporters and drug resistance in breast cancer. Endocr Relat Cancer. 2003; 10(1):43-73.

52. Whistler JL, Chuang HH, Chu P, Jan LY and von Zastrow M. Functional dissociation of $\mathrm{mu}$ opioid receptor signaling and endocytosis: implications for the biology of opiate tolerance and addiction. Neuron. 1999; 23(4):737-746.

53. Karin M. Signal transduction from the cell surface to the nucleus through the phosphorylation of transcription factors. Curr Opin Cell Biol. 1994; 6(3):415-424. 
54. Boucher MJ, Duchesne C, Laine J, Morisset J and Rivard $\mathrm{N}$. cAMP protection of pancreatic cancer cells against apoptosis induced by ERK inhibition. Biochem Biophys Res Commun. 2001; 285(2):207-216.

55. Garcia-Bermejo L, Perez C, Vilaboa NE, de Blas E and Aller P. cAMP increasing agents attenuate the generation of apoptosis by etoposide in promonocytic leukemia cells. J Cell Sci. 1998; 111 ( Pt 5):637-644.

56. Sastry KS, Karpova Y, Prokopovich S, Smith AJ, Essau B, Gersappe A, Carson JP, Weber MJ, Register TC, Chen YQ, Penn RB and Kulik G. Epinephrine protects cancer cells from apoptosis via activation of cAMP-dependent protein kinase and BAD phosphorylation. J Biol Chem. 2007; 282(19):14094-14100.

57. Kwon G, Pappan KL, Marshall CA, Schaffer JE and McDaniel ML. cAMP Dose-dependently prevents palmitate-induced apoptosis by both protein kinase Aand cAMP-guanine nucleotide exchange factor-dependent pathways in beta-cells. J Biol Chem. 2004; 279(10):89388945.

58. Bok J, Zha XM, Cho YS and Green SH. An extranuclear locus of cAMP-dependent protein kinase action is necessary and sufficient for promotion of spiral ganglion neuronal survival by cAMP. J Neurosci. 2003; 23(3):777-787.

59. Webster CR, Usechak P and Anwer MS. cAMP inhibits bile acid-induced apoptosis by blocking caspase activation and cytochrome c release. Am J Physiol Gastrointest Liver Physiol. 2002; 283(3):G727-738.

60. Webster CR and Anwer MS. Cyclic adenosine monophosphate-mediated protection against bile acidinduced apoptosis in cultured rat hepatocytes. Hepatology. 1998; 27(5):1324-1331.

61. Safa M, Zand H, Mousavizadeh K, Kazemi A, Bakhshayesh $\mathrm{M}$ and Hayat P. Elevation of cyclic AMP causes an imbalance between NF-kappaB and p53 in NALM-6 cells treated by doxorubicin. FEBS Lett. 2010; 584(15):34923498.

62. Hilger RA, Richly H, Grubert M, Oberhoff C, Strumberg D, Scheulen ME and Seeber S. Pharmacokinetics (PK) of a liposomal encapsulated fraction containing doxorubicin and of doxorubicin released from the liposomal capsule after intravenous infusion of Caelyx/Doxil. Int J Clin Pharmacol Ther. 2005; 43(12):588-589.

63. Richly H, Henning BF, Kupsch P, Passarge K, Grubert M, Hilger RA, Christensen O, Brendel E, Schwartz B, Ludwig M, Flashar C, Voigtmann R, Scheulen ME, Seeber S and Strumberg D. Results of a Phase I trial of sorafenib (BAY 43-9006) in combination with doxorubicin in patients with refractory solid tumors. Ann Oncol. 2006; 17(5):866-873.

64. Workman P, Aboagye EO, Balkwill F, Balmain A, Bruder G, Chaplin DJ, Double JA, Everitt J, Farningham DA, Glennie MJ, Kelland LR, Robinson V, Stratford IJ, Tozer GM, Watson S, Wedge SR, et al. Guidelines for the welfare and use of animals in cancer research. Br J Cancer. 2010; 102(11):1555-1577.
65. Hedin KE, Bell MP, Kalli KR, Huntoon CJ, Sharp BM and McKean DJ. Delta-opioid receptors expressed by Jurkat $\mathrm{T}$ cells enhance IL-2 secretion by increasing AP-1 complexes and activity of the NF-AT/AP-1-binding promoter element. J Immunol. 1997; 159(11):5431-5440.

66. Carbonari M, Cibati M, Cherchi M, Sbarigia D, Pesce AM, Dell'Anna L, Modica A and Fiorilli M. Detection and characterization of apoptotic peripheral blood lymphocytes in human immunodeficiency virus infection and cancer chemotherapy by a novel flow immunocytometric method. Blood. 1994; 83(5):1268-1277.

67. Nicoletti I, Migliorati G, Pagliacci MC, Grignani F and Riccardi C. A rapid and simple method for measuring thymocyte apoptosis by propidium iodide staining and flow cytometry. J Immunol Meth. 1991; 139:271-279.

68. Friesen C, Glatting G, Koop B, Schwarz K, Morgenstern A, Apostolidis C, Debatin KM and Reske SN. Breaking chemoresistance and radioresistance with [213Bi]antiCD45 antibodies in leukemia cells. Cancer Res. 2007; 67(5):1950-1958.

69. Roscher M, Hormann I, Leib O, Marx S, Moreno J, Miltner E and Friesen C. Targeted alpha-therapy using [Bi213] anti-CD20 as novel treatment option for radio- and chemoresistant non-Hodgkin lymphoma cells. Oncotarget. 2013; 4(2):218-230.

70. Classen CF, Falk CS, Friesen C, Fulda S, Herr I and Debatin KM. Natural killer resistance of a drug-resistant leukemia cell line, mediated by up-regulation of HLA class I expression. Haematologica. 2003; 88(5):509-521. 